\title{
Five bid to host Middle East synchrotron
}

[PARIS] A proposal for an international research centre in the Middle East, built around a synchrotron to be donated by Germany, was officially launched at a meeting in Paris last week. Bids to host the centre were submitted by Turkey, Cyprus, Iran, the Palestinian Authority and Egypt.

A final decision on the location will be taken by an interim governing council, including two representatives from each of the candidate countries (see Nature 399, 507-508; 1999).

Delegates have promised to support the project even if the site does not fall in their home country. In a bid to accelerate the approval process, the meeting called on states in the Middle East to confirm their approval by 31 July. There was considerable praise for Israel's commitment to the project without bidding to host the facility, out of recognition that a centre in Israel would attract little participation from many of its neighbours.

"The project would not work without Israel," says Siegbert Raither of the United Nations Educational, Scientific and Cultural Organization (Unesco), which hosted last week's meeting. "Israel is a very important ingredient to the scientific success of this institution," he says.

Participants at the meeting acknowledged that funding is now their biggest priority. But raising the required amount - at least US\$30 million — will not be easy.

\section{Israel 'must relax technology transfer law'}

[JERUSALEM] Orna Berry, chief scientist in Israel's Ministry of Commerce and Industry, acknowledged last week that the country's law on research and development (R\&D) needs to be revised to take into account changes in intellectual property rights and technology exports.

Her statement reflects growing pressure on the government to liberalize its policy on technology transfer, and to lift restrictions requiring the application of government-funded research to take place primarily in Israel.

Berry says that her office is planning to submit to the new Knesset, the Israeli parliament, proposals to modify the R\&D law to allow greater flexibility in the exploitation of government-funded research. But many in the country's hightech industries argue that the proposed changes do not go far enough.

Speaking at a seminar at Ben-Gurion University in Be'ersheva, Berry said that, although she has much flexibility under the current law, she would prefer to see these policies inserted explicitly into the law.

According to government officials, the main problem with intellectual property rights in Israel is that companies are often unaware of the value of their ideas, and sell them overseas too cheaply. One official estimates that there are 30 such cases a year.

Berry argues that the R\&D law needs to be changed to defend Israel's intellectual property, but without restricting the marketplace. For example, the law requires that a company receiving an $R \& D$ grant from the government must carry out its production in Israel or return the grant. This dissuades some start-up companies that expect to need overseas partnership from applying for government assistance.

Berry supports this requirement as necessary to job creation in Israel. But she acknowledges that there are cases in which overseas production is more profitable, and argues that the law should be changed to allow for them. It should also help Israeli firms to acquire the managerial and marketing know-how needed to make local production profitable, she said.

Another gap in the law concerns mergers and acquisitions. Companies that receive grants must pay royalties to the government out of their sales. But many companies are bought by foreign companies before there is any production, and the government loses its investment.

Berry wants the law changed so that companies bought out in this way must still repay their grants. Her insistence that most high-tech production should be carried out in Israel was criticized by many industry representatives at the seminar, especially those involved in biotechnology, where investors and industrialists see overseas production and marketing as important elements in developing Israel's potential.

Critics argue that, although Israel's life scientists produce good research, the local management and marketing expertise needed to turn research into commercial products is lacking. "No government policy in the world has made a difference for biotechnology - it all comes from the market," said Ehud Geller of Medica Venture Partners, a biotech venture-capital firm.

Geller said that the Israeli government should let the market do its work, including allowing foreign companies to acquire Israeli technologies.

Geller said pension funds and insurance companies - the largest investors in the country - invest almost nothing in biotech because of government restrictions and negative incentives.

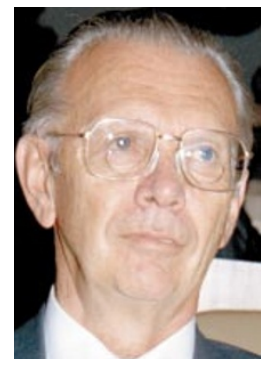

Schopper: keen for a quick decision.
Funds for the project are unlikely to emerge until a decision has been made on the centre's location. This is partly because Western governments may be reluctant to commit money to a centre in any country where diplomatic ties are weak.

The proposal is based around an offer from Germany to donate BESSY-1, a 14-year-old, fully functioning, $0.8 \mathrm{GeV}$ synchrotron in Berlin. But Germany may not be prepared to commit the extra costs of dismantling the machine for later use without a firm indication that the centre will be funded.

"The BESSY directorate is looking for a quick decision, as there is a [financial] difference between the machine being scrapped or being dismantled for further use," says Herwig Schopper, a former director-general of the European Laboratory for Particle Physics (CERN). Schopper, who was elected president of the project's interim council last week, emphasizes that the timetable is tight. BESSY-1 is due to be taken out of service at the end of the year.

Potential sources of funding include the European Union and the Middle East finance package tied to the Wye Agreement, which is working its way through the US Congress. President Bill Clinton is understood to have requested $\$ 1.2$ billion for Israel, \$400 million for the Palestinian Authority and $\$ 300$ million for Jordan.

Observers believe that the costs of the war in Kosovo could mean that Congress is unlikely to agree to the sum requested by Clinton. And most of the Wye package is understood to be earmarked for roads, hospitals and schools. William McIlhenny, the US government's permanent observer to Unesco, says a key question is whether governments are prepared to allocate large sums for a synchrotron facility instead of more pressing problems such as clean water and sewage disposal.

A centre based in the Palestinian Authority is likely to be convenient for Israel. But the Palestinian bid, along with those from other candidate hosts - except Egypt, and possibly Iran — will need significant external financing.

But, despite the difficulties, participants left Paris in optimistic mood. "With the response we've gotten, and Unesco's strong support, I am convinced that we will get the money," says Herman Winick of the Stanford Linear Accelerator Centre in California, one of the project's co-founders. Heather McCabe 